\title{
Consequences of Dam Removal on Mussel Assemblages (Unionidae) in the Cuyahoga River
}

NICHOLAS P. HOGYA and RACHEL E. ANDRIKANICH, Department of Biological, Geological and Environmental Sciences, Cleveland State University, 2121 Euclid Ave., Cleveland, OH 44115; RYAN J. TRIMBATH, Summit Metro Parks, 2400 Sand Run Parkway, Akron, OH 44333 (present address: Dept. of Biology, University of Akron, Akron OH); and ROBERT A. KREBS', Department of Biological, Geological and Environmental Sciences, Cleveland State University, 2121 Euclid Ave., Cleveland, $\mathrm{OH} 44115$, USA.

ABSTRACT. The primary objective of a new survey of the Cuyahoga River was to assess species richness and population abundance of various mussel species in the family Unionidae throughout the Middle Cuyahoga River and upper parts of the Lower Cuyahoga River. Historically, few records existed for this river between Lake Rockwell and the Cuyahoga Valley National Park, a region in which four dams have been removed in the past 12 years. Timed visual surveys were conducted during low flow conditions and by using tactile techniques in deeper water. Throughout the survey, only 37 live animals were located across the 18 Middle Cuyahoga River sites inspected, which included only Lampsilis siliquoidea, Pyganodon grandis and the state-endangered Ligumia nasuta. No live mussels were found between the Gorge and the Cuyahoga Valley National Park. That $\mathbf{4 3 4}$ shells and valves were collected, and all but two were classified as long dead, attests that mussels had been more abundant, and that at least nine of the ten species known to be present above Lake Rockwell had lived in the Middle Cuyahoga River. Remote sensing data and aerial photographs were used to characterize change in opening up the river, but benefits to water quality and stream flow subsequent to dam removal must be tempered with the apparent loss of an assemblage of mussels better adapted to lentic conditions.

\section{INTRODUCTION}

Dam removal is gaining popularity both to solve problems of dangerous structures and to restore river habitat (Poff and Hart 2002; Hornbach et al. 2014). However, the vast sediment loads stored behind dams and the potential for downstream deposition following removal can create a disturbance outside the typical range for an ecosystem (Resh et al. 1988; Poff 1992). Such physical disturbances may be expected to kill or displace many resident organisms in the short term (Tulos et al. 2014), although long-term benefits to reconnect populations are predicted to outweigh short-term costs (Randklev et al. 2016).

Several dams have been removed from the Cuyahoga River (Ohio), a place named by President Clinton in 1998 as one of fourteen American Heritage Rivers. Pollution in this watershed remains part of U.S. history (Stradling and Stradling 2008) for stimulating formation of the EPA in 1970, the Clean Water Act in 1972, and subsequently the Great Lakes Water Quality agreement by the International Joint Commission

${ }^{1}$ Address correspondence to Dr. Bob Krebs, Dept. of BGES, 2121 Euclid Ave., Cleveland State University, Cleveland, $\mathrm{OH}$ 44115. Email: r.krebs@csuohio.edu, 216-523-7553.
(IJC). In 1985 the Water Quality Board of the IJC designated the Cuyahoga as one of 43 Areas of Concern that contributes to the degraded condition of the Great Lakes, with nine of 14 beneficial-use impairments defined by the IJC designated as a problem in sections of the Cuyahoga River and its lower tributaries (http:// www.cuyahogaaoc.org/ accessed Aug. 2, 2016). Much of the attention focused on the lower Cuyahoga River watershed, and as a consequence, the main stem and its largest tributaries (Big Creek, Tinkers Creek and the Little Cuyahoga River) have been regularly surveyed and assessed by the Ohio EPA since 1984 (OEPA 1999; 2003). The Northeast Ohio Regional Sewer District (NEORSD) began an integrated monitoring and assessment program in 1990, and presently evaluates the lower 16 river miles of the Cuyahoga River on an annual basis. Most of the beneficial use impairments have been removed, the Cuyahoga River is open again for recreation, and fish diversity has steadily improved (http://www.stowsentry.com/regional/2016/06/13/ twoday-bioblitz-observers-recorded-815-speciesin-cuyahoga-valley-national-park, accessed July 29, 2016). However, the impact of dam removal in the 
Middle Cuyahoga River was never assessed for mussels or fish, and this region carries importance as potential habitat of the state-endangered mussel species, Ligumia nasuta (Eastern Pondmussel), in addition to nine other mussels from the same family known to occur in the upper reaches of the Cuyahoga River (Tevesz et al. 2002; Krebs et al. 2012).

As far back as the early 1900's, Arnold Ortmann (1919) characterized anthropogenic impacts to macroinvertebrate communities, predicting that mussels in the family Unionidae would be the first lost in damaged freshwater systems and the last to recover. Biogeographically, freshwater mussels are one of the few groups of bivalves adapted to flowing water, as they briefly parasitize fish hosts during their larval form to hitch a ride upstream (Schwalb et al. 2013). They subsequently drop from a fish and begin a largely sedentary existence, some reaching sizes of $25 \mathrm{~cm}$ in length and ages exceeding 50 years (Haag and Rypel 2011). Their shells are an enigma for their size, and they have provided the region brief economic boons from freshwater pearls in the late 1800's, buttons in the early 1900's, and lastly as seed stock for cultured pearls (Anthony and Downing 2001). Now they are too often rare, and mussels are recognized too late as an important part of the ecosystem (Pires et al. 2007).

We report on the Unionidae of the Cuyahoga River within Summit County, Ohio, an area once significantly impounded by six dams of at least $3 \mathrm{~m}$ in height (Fig. 1 ), but now more open after removal of four of these dams and converting of their impoundment areas to a flowing stream. This change has taken just 10 years (2004-2013) and includes (1) the Gorge Dam, the largest at 17.4-m-tall and constructed in 1912 (extant, removal under review), (2) Sheraton Dam at $3 \mathrm{~m}$ built between 1914 and 1918 for the Vaughn Machinery Company, removed in 2013, (3) Le Fever Powerhouse Dam at $3.4 \mathrm{~m}$ built in 1914 to supply power for the Walsh Paper Company, removed in 2013, (4) Munroe Falls Dam at $3.5 \mathrm{~m}$ and dating to 1817 (Gottgens and Evans 2007), removed in 2005, (5) Kent Dam, a $4.3 \mathrm{~m}$ masonry dam built in 1836 , was bypassed in 2004 with the historic spillway retained, and (6) Lake Rockwell Dam, constructed in 1915, extant (provides water to the city of Akron).

Surveys were conducted in the summer of 2015 to determine what mussel species remain in the Middle Cuyahoga River. The work extended downstream to the Cuyahoga Valley National Park, which is another area well studied for anthropogenic impacts (OEPA

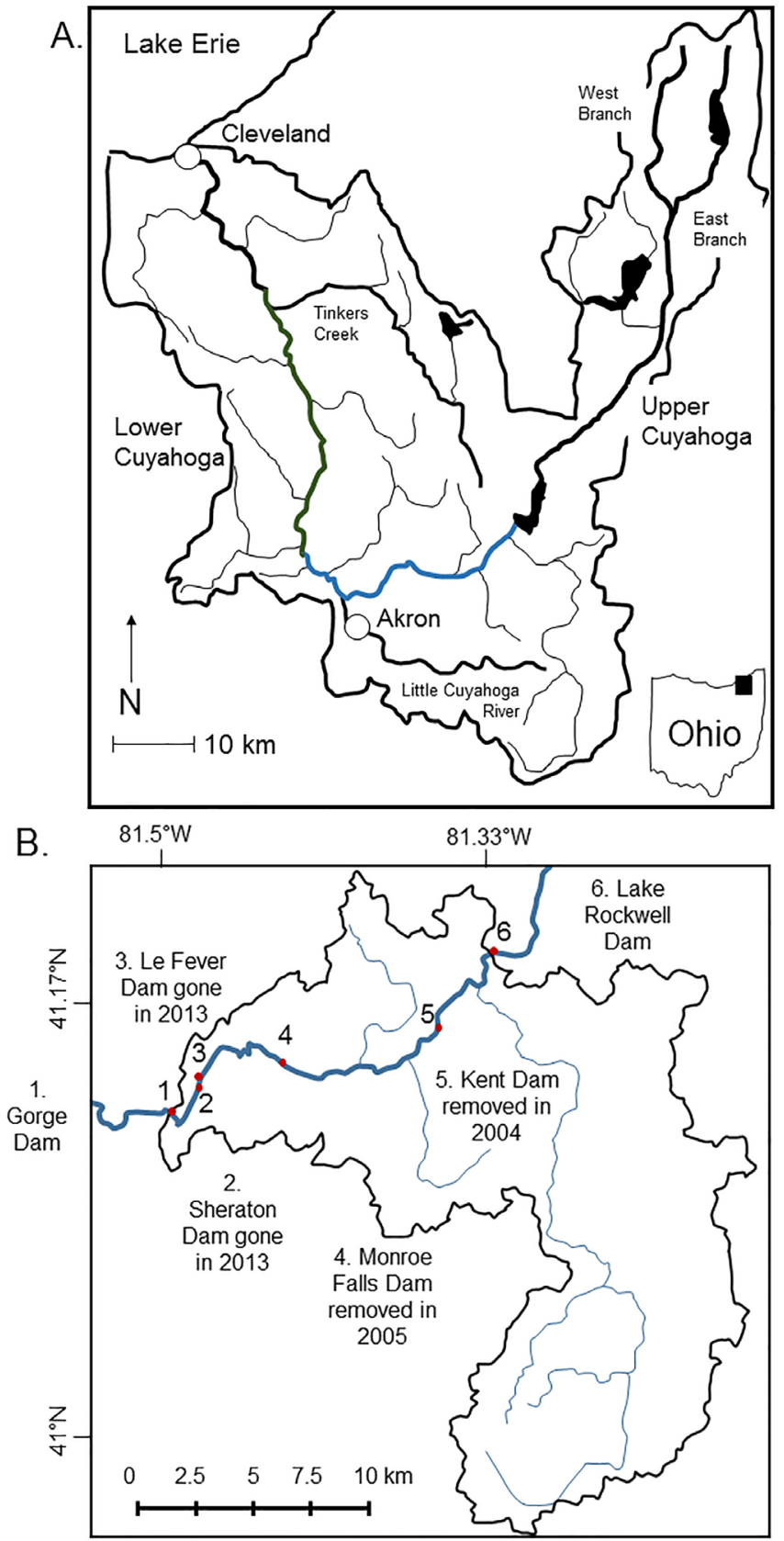

Figure 1. The Cuyahoga River watershed in Ohio (A), with blue indicating the present survey area and green the region flowing through the Cuyahoga Valley National Park, and (B) showing the boundaries, tributaries and locations of historic dams in the Middle Cuyahoga River (modified from Mann et al.2013): (1) Gorge Dam, (2) former Sheraton Dam, (3) former Le Fever Dam, (4) former Munroe Falls Dam, (5) former Kent Dam and (6) Lake Rockwell Dam.

2000, Peck 2012). For continuity, surveys also extended upstream to the slack-water below Lake Rockwell Dam in Portage County, and several sites above the lake were examined akin to outgroup sites, as this area was known to contain a more abundant assemblage of mussels (Tevesz et al. 2002). 


\section{METHODS}

A survey of the Cuyahoga River between the Cuyahoga Valley National Park and the dam forming Lake Rockwell included 21 sites where mussel presence (alive and dead) was determined, and three more sites above Lake Rockwell were surveyed, but only for live mussels (Table 1). Intensive searches were made by 2-4 individuals, usually for 2-3 person hrs (15 sites) and $58 \mathrm{hrs}$ total in stream, often walking through long stretches of the river with a goal of finding reasonable habitat for mussels (soft stream bottom) and ultimately mussels. A minimum of 1 person hour $(2 \mathrm{~h}$ where any reasonable habitat occurred) was invested at all sites. While not quantitative, such timed searches are predicted to increase the chances to find a larger diversity of living species and the number of shells recovered.
Search methods varied in response to substrate type, water clarity, and water depth but the opened flowing river post-dam removal (Fig. 2), and the timing of surveys when water levels declined below average in the low-flow time of year, allowed mainly visual surveys. However, surveys were sometimes tactile where water was highly turbid. Visual surveys are especially efficient for the discovery of shells from which the nacre is reflective and siphons can be spotted for even wellembedded mussels. Live animals were identified in the field, each was photographed, except where a modest number of Lampsilissiliquoidea (Fatmuckets) occurred at one site, and returned to the substrate. Shells were bagged in the field and brought to the lab to confirm species, and to assemble a voucher collection.

Physical change in the river was assessed preliminarily from Google Earth images, and then more intensively
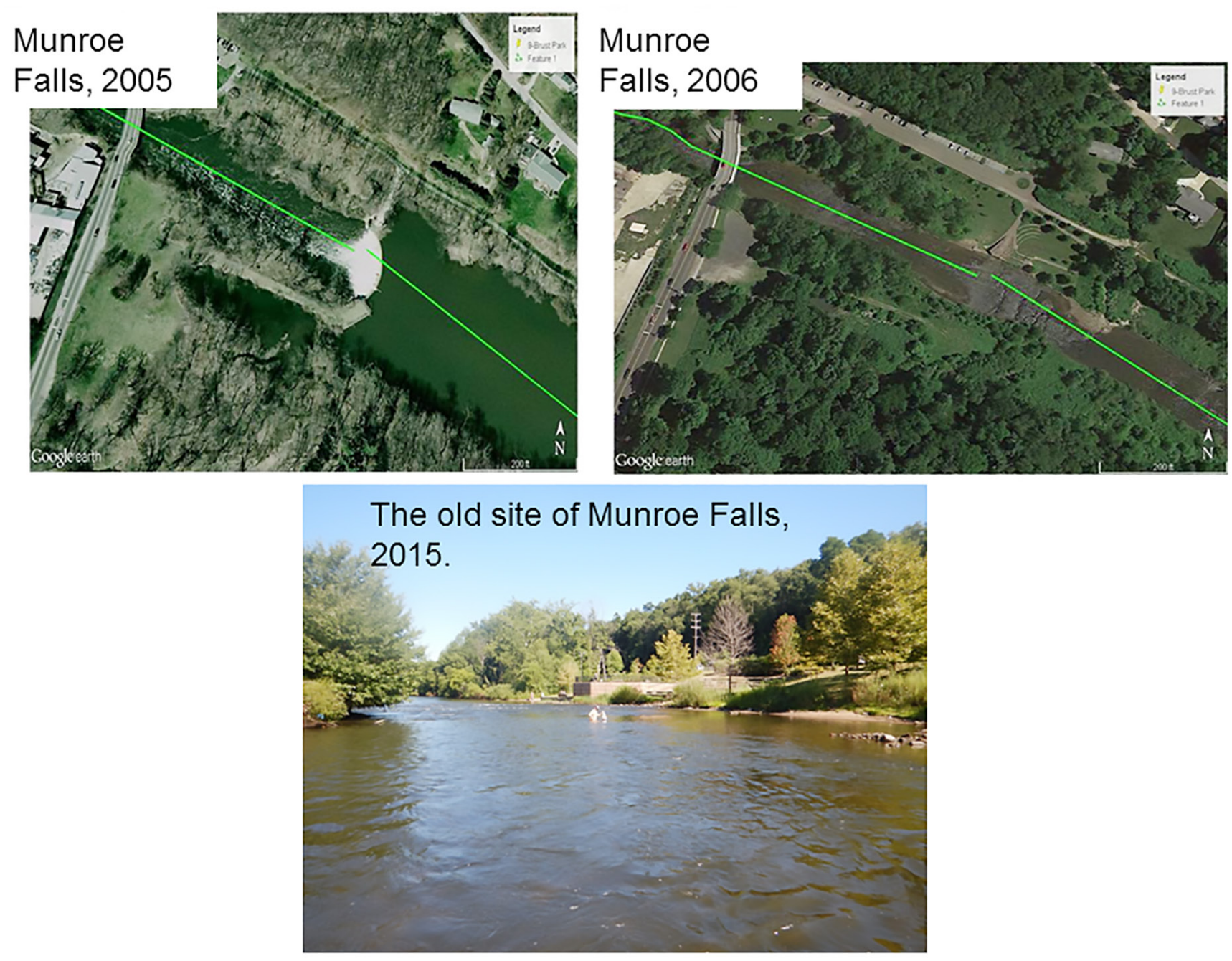

Figure 2. Changes in the Cuyahoga River after removal of the dam at Munroe Falls are visible from Google Earth aerial photographs, first from 2005 (top left) before the dam was removed, and a year later (top right) after removal. The river has changed completely from a lentic (lacustrine) to a lotic (riverine) environment (bottom). 
Table 1

Site locations and effort in person hours for mussel surveys between the southern end of the Cuyahoga Valley National Park (sites 1-3 were below the Gorge) and the Upper Cuyahoga River (sites 22-24 above Lake Rockwell). Eighteen sites (4-21) spanned the Middle Cuyahoga River. The number of live animals and number of shells found during the surveys also are given.

\begin{tabular}{|c|c|c|c|c|c|}
\hline Site & Place Name & $\begin{array}{l}\text { Entry Point } \\
\text { Coordinates } \\
\text { (lat., long.) }\end{array}$ & $\begin{array}{l}\text { Search Time } \\
\text { (hrs) }\end{array}$ & Live & Shells \\
\hline 1 & The Valley & $41.1413,-81.5622$ & 4 & 0 & 0 \\
\hline 2 & Akron-Peninsula Rd. & $41.1360,-81.5479$ & 2.5 & 0 & 1 \\
\hline 3 & Akron-Peninsula Rd. & $41.1360,-81.5479$ & 2.5 & 0 & 0 \\
\hline 4 & Cuyahoga St. & $41.1169,-81.5250$ & 1 & 0 & 0 \\
\hline 5 & State Rd. & $41.1234,-81.5123$ & 1.5 & 0 & 0 \\
\hline 6 & Falls Rd. & $41.1283,-81.4841$ & 2 & 0 & 1 \\
\hline 7 & Oak Park downstream & $41.1483,-81.4678$ & 3 & 0 & 25 \\
\hline 8 & Oak Park upstream & $41.1483,-81.4678$ & 2.5 & 0 & 41 \\
\hline 9 & Water-works downstream & $41.1447,-81.4593$ & 2 & 0 & 51 \\
\hline 10 & Water-works upstream & $41.1447,-81.4593$ & 3 & 0 & 56 \\
\hline 11 & Bike $\&$ Hike Trail & $41.1478-81.4495$ & 2 & 0 & 28 \\
\hline 12 & Brust Park & $41.1428,-81.4392$ & 2 & 0 & 10 \\
\hline 13 & Brust Park upstream & $41.1418,-81.4368$ & 2 & 0 & 0 \\
\hline 14 & Riverside Park & $41.1384,-81.4120$ & 12 & 5 & 41 \\
\hline 15 & Middlebury Bridge & $41.1378,-81.3910$ & 3.5 & 4 & 91 \\
\hline 16 & Bike-Train Bridge & $41.1430,-81.3730$ & 2 & 1 & 14 \\
\hline 17 & Fuller Park downstream & $41.1498,-81.3671$ & 2.7 & 5 & 13 \\
\hline 18 & Fuller Park upstream & $41.1498,-81.3671$ & 3 & 20 & 25 \\
\hline 19 & Foot Bridge & $41.1590,-81.3590$ & 1 & 0 & 0 \\
\hline 20 & Knolls Rd. & $41.1685,-81.3466$ & 1.5 & 1 & 34 \\
\hline 21 & Ravenna Rd. & $41.1799,-81.3360$ & 2.8 & 1 & 3 \\
\hline 22 & St 303 & $41.2449,-81.2859$ & 2 & 23 & not recorded ${ }^{1}$ \\
\hline 23 & St 164 & $41.2689,-81.2463$ & 2 & 38 & not recorded ${ }^{1}$ \\
\hline 24 & camp hi (Abbott Rd) & $41.3266,-81.1726$ & 2 & 127 & not recorded ${ }^{1}$ \\
\hline
\end{tabular}


from NAIP images (National Agriculture Imagery Program, which acquires aerial imagery during the agricultural growing seasons) that were obtained for 2004 (prior to dam removal) and from the study year, 2015. In addition, a 2006 Color-infrared (CIR) image, digital elevation models (DEM) and digital surface models (DSM) were created to apply segmentation and classification in a raster image analysis software suite (eCognition, Trimble, http://www.ecognition. $\mathrm{com} /$, accessed May, 2016) with a scale parameter of 25 and a spectral difference of 2 for the segmentation. All the different images were resampled to the same pixel size of $1 \mathrm{~m}$ for use in eCognition. Nine land-use classes were established for the Cuyahoga River and its riparian zone, defined as the area within $20 \mathrm{~m}$ of the river.

A $30 \mathrm{~m}$ thematic buffer layer (a polygon vector file) was applied using a geographic information system (ArcMap, http://desktop.arcgis.com/en/arcmap/, accessed May, 2016) to generate a second analysis of land cover surrounding the Cuyahoga River, and one more visually presentable. The location of the mussels found in the region were mapped on this second image set, which more accurately depicted anthropogenic effects on the land cover classification for the Cuyahoga River buffer.

\section{RESULTS}

Few live mussels were found in the Middle Cuyahoga River, and none were found in the lower river between the Cuyahoga Valley National Park and the Gorge region (sites 1-3, Table 1). Of the 37 individuals found (Table 2), most were Lampsilis siliquoidea, and most occurred at one site (\#18, Fuller Park, Table 1) where they were imbedded in mud along an excised bank. Many more shells were found than live animals, and they included examples of nine of the ten species predicted to be in the region (Table 2). Only shells of Anodontoides ferussacianus were lacking. Somewhat unusual is that when mussels were observed, the individual often was not deeply imbedded into substrate (Fig. 3), and several were not imbedded at all. Instead they were observed lying on their side, two of which had washed onto exposed areas.

Table 2

A summary of the live Unionid mussel species found in the Middle Cuyahoga River and in 3 sites above Lake Rockwell; no mussels were found below the Gorge (Lower Cuyahoga River).

\begin{tabular}{llccc}
\hline \hline $\begin{array}{l}\text { Species Known from the } \\
\text { Upper Cuyahoga River }\end{array}$ & Common Names & $\begin{array}{c}\text { Predominant } \\
\text { Stream Flow } \\
\text { Habitat }\end{array}$ & $\begin{array}{c}\text { Alive-Middle } \\
\text { Cuyahoga } \\
\text { (18 sites) }\end{array}$ & $\begin{array}{c}\text { Alive - Upper } \\
\text { Cuyahoga } \\
\text { (3 sites) }\end{array}$ \\
\hline Lampsilis siliquoidea & Fatmucket & lentic/lotic & 28 & 132 \\
Lasmigona complanata & White Heelsplitter & lotic & 0 & 0 \\
Lasmigona compressa & Creek Heelsplitter & lotic & 0 & 0 \\
Lasmigona costata & Fluted Shell & lotic & 0 & 4 \\
Ligumia nasuta & $\begin{array}{l}\text { Eastern } \\
\text { Pondmussel }\end{array}$ & lentic & 3 & 38 \\
Pyganodon grandis & Giant Floater & lentic & 6 & 0 \\
Strophitus undulatus & Creeper & lotic & 0 & 0 \\
Toxolasma parvum & Lilliput & lentic & 0 & 0 \\
Utterbackia imbecillis & Paper Pondshell & lentic & 0 & 188 \\
Total specimens & & & 37 & \\
1 from Watters et al. (2009) & & & & 0 \\
\hline
\end{tabular}



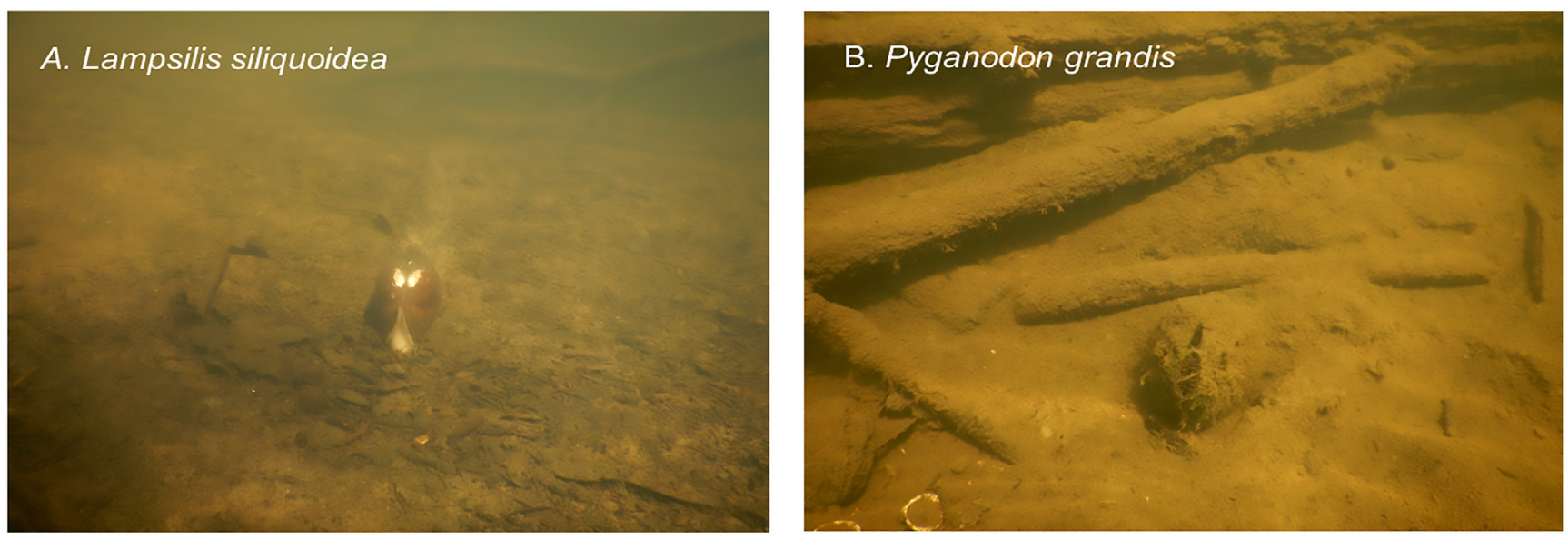

Figure 3. Two of the live mussels observed in visual searches: A., a L. siliquoidea extending its foot with trail visible behind it, and B., a Giant Floater with siphons open, feeding in the water column.

\section{A. Digital Elevation Model, red is higher elevation and blue, lower}

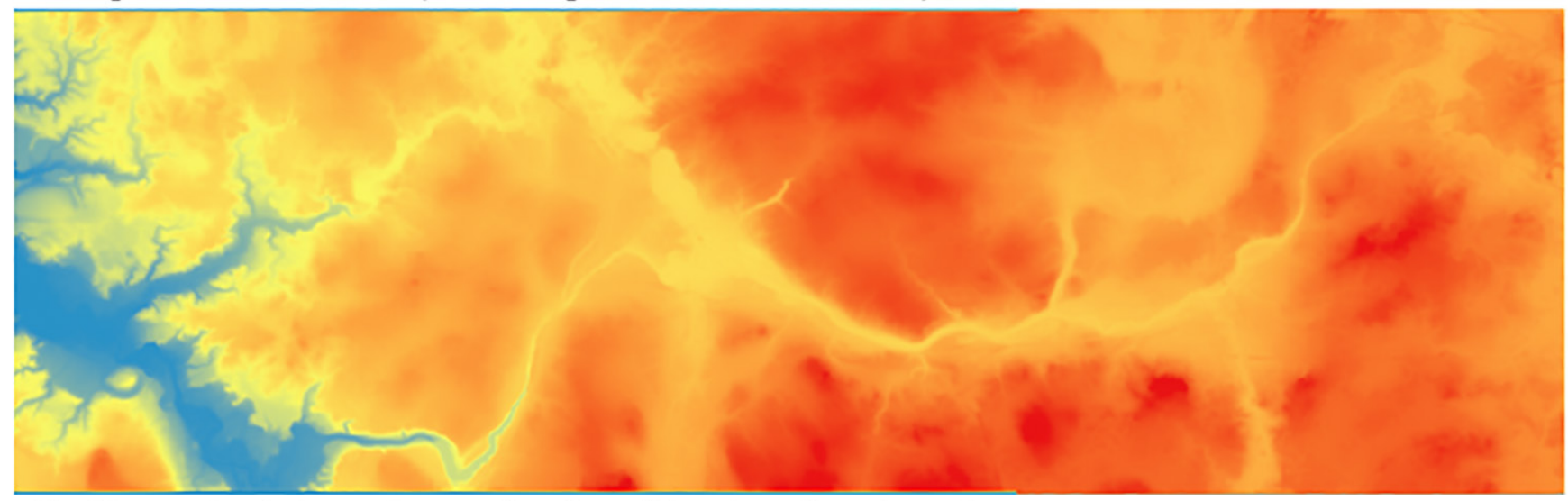

B. Stream bed slope, increasing from blue to yellow to red

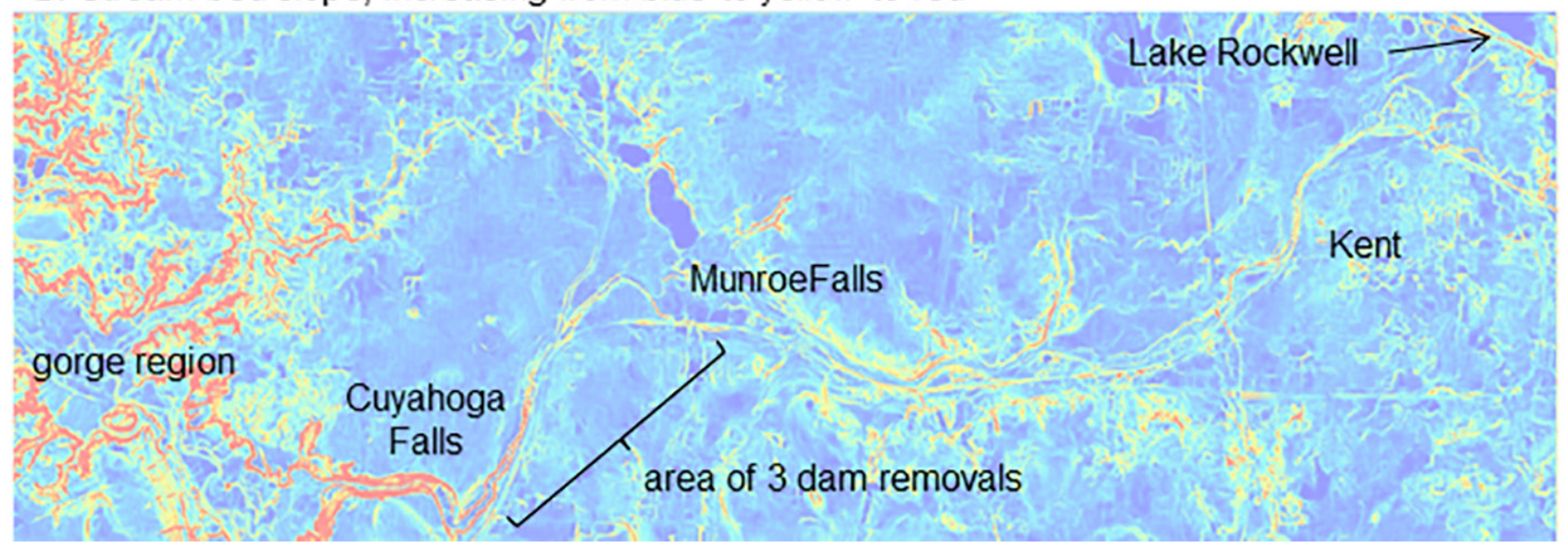

Figure 4. A representation of elevation (above) and stream slope (below) along the Middle Cuyahoga River descending into the gorge, which sets the boundary with the Lower Cuyahoga River. Increased slope is indicated by shifts to yellow and then red along the river. 
Current mussel habitat was assessed from digitized imagery of stream slope as an indicator of flow, shear stress and land use. Slope increased downstream in the Middle Cuyahoga (Fig. 4) as the river approached the gorge region. Classification of land use varied in a pattern following stream slope, with increased urbanization concordant with greater slope (perhaps because dams built here once provided electrical power to industry and local communities). Thus, comparison to land cover classifications suggested that every one of the 37 live mussels were collected in areas classified as "deciduous forest" (Fig. 5), which were areas with dense tree cover, and these areas lay above the region of high slope (Fig. 4b). All other nine potential classes held no individuals at all.

Invasive mussel species were observed but not counted. Shells of Corbicula were abundant throughout the old dam sites (numbering in the thousands). At the top of the Middle Cuyahoga River below Lake Rockwell, Dreissenidae, zebra (Dreissena polymorpha) and/or quagga (D. rostriformis bugensis) mussels, were observed on rocks and other debris, and covered the exposed surface of the one live unionid mussel found at site 21 .

\section{DISCUSSION}

Freshwater mussels of the family Unionidae have fared poorly despite dam removals in the Middle Cuyahoga River made to improve water quality and appearance for recreational use. Live animals were found of just three species, Lampsilis siliquoidea
(Fatmucket), Ligumia nasuta (Eastern Pondmussel), and Pyganodon grandis (Giant Floater), although six other species were found as shells indicating either past presence or that existing populations are below detectable limits for the methods applied here. Dams can have diverse impacts on mussel assemblages both upstream and downstream (Stanley et al. 2002; Sethi et al. 2004). Dams predominantly affect flow and sedimentation downstream, which can benefit some species (Randklev et al. 2015), but not others (Vaughn and Taylor 1999; Hardison and Layzer 2001), and they also act as a barrier to dispersal and gene flow (Watters 1996, Krebs et al. 2010a). Thus the survey described here must be placed in the context of examining a river in flux. Past dams affected mussel assemblages, and their removal may impose a different set of stresses as habitat changed (Stanley and Doyle, 2003).

Few results exist on how much time is needed before mussels recolonize an altered river bed, although recovery of assemblages can take decades where large stretches of a stream are affected (Sietman et al. 2001). In one Cuyahoga River tributary, Tinkers Creek, Craig and Krebs (2014) found locally that mussels had returned to a man-made section of river bed after about 12 years following an intentional movement of the stream in Twinsburg, OH in 1998 (Krebs et al. 2002). The habitat today surrounding and upstream of that stretch of river includes thick riparian zones of wetlands and deciduous trees, and therefore change was pronounced only for about $350 \mathrm{~m}$. In contrast, the series of dams in the Middle Cuyahoga River

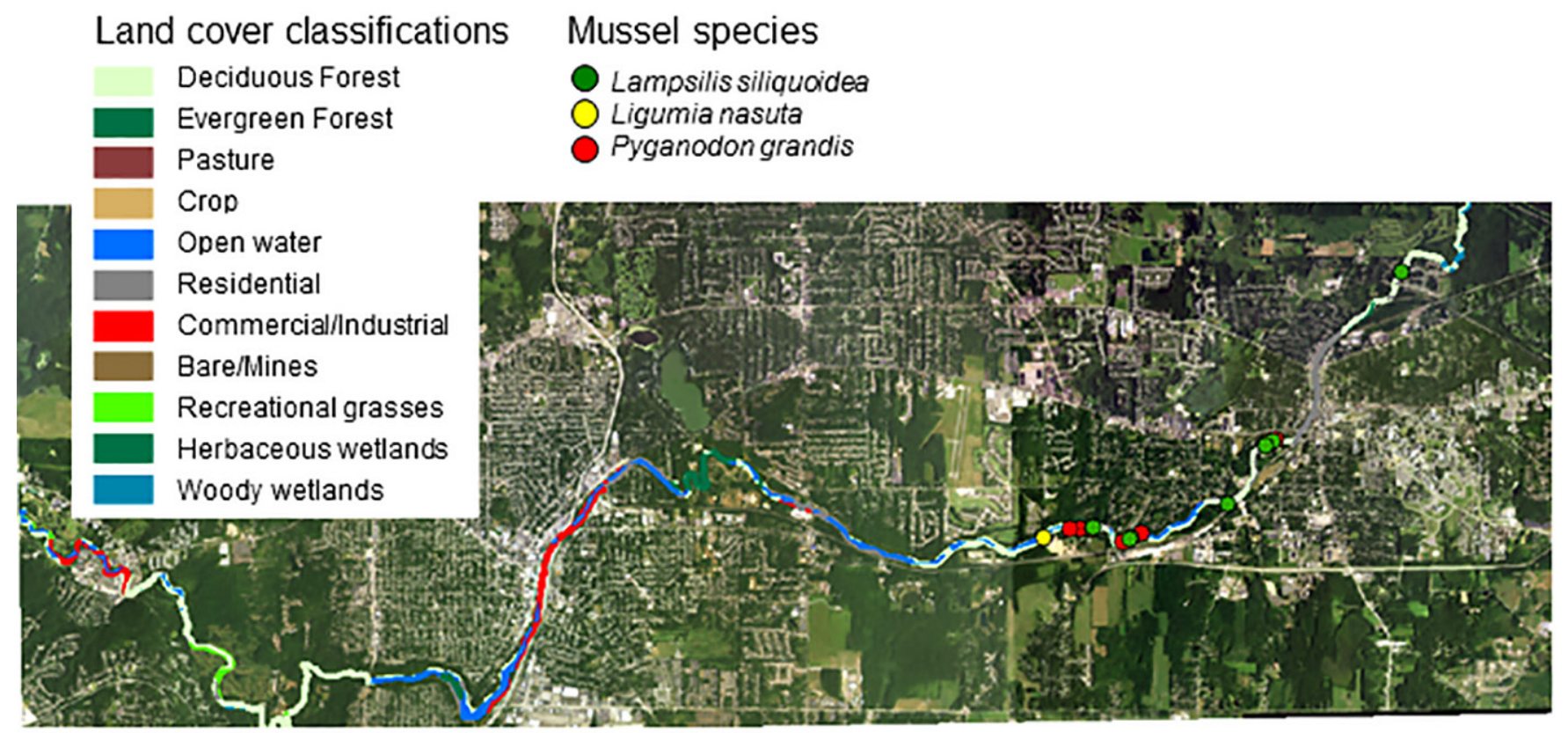

Figure 5. Land use cover and locations of all mussels found living in the Middle Cuyahoga River in the summer of 2015. 
created an almost continuous dam pool, and their removal would have distributed vast quantities of sediment downstream and led to significant changes in the structure of the riverbed (Doyle et al. 2005; Gottgens and Evans 2007; Tuckerman and Zawiski 2007; Mann et al. 2013).

Of the three mussel species found alive in this study, P. grandis, L. siliquoidea and L. nasuta, all occur commonly in slow moving water, and only $L$. siliquoidea is abundant in both flowing streams and in slack water (Watters et al. 2009). That $P$. grandis and $L$. siliquoidea can also tolerate agricultural inputs (Begley 2014) contributes to their being the two most common species statewide, while the cause of the limitation of the $L$. nasuta only to the Cuyahoga River above the gorge is unclear. Ligumia nasuta is an Atlantic Coastal species and perhaps only a historic chance event of dispersal or human introduction brought the species to Lake Erie and the Cuyahoga River (Graf 2002; Scott et al. 2014), although the species is all but lost from Lake Erie today after the dreissenid invasion (Zanatta et al. 2015).

The diversity and abundance of shells suggests that high mortality of mussels followed dam removal, especially of lentic species in the past dam pools, as Sethi et al. (2004) observed in a similarly sized river. Species more often found in lotic habitat were rare, although failure to find a species only means that the density is below detectable limits. Freshwater mussels are well hidden and sometimes difficult to find without destructive sampling (Wisniewski et al. 2013). However, given extensive search time in the water, and that surveys primarily applied visual assessment of the stream bed along what is not a long stretch of river, populations of other species cannot be large. The ratio of 11.7 shells for every live mussel observed is also unusually high, and using similar survey protocols, the only local area where a higher ratio was found and live mussels were obtained was the urbanized lower Chagrin River; 6 live Lampsilis cardium (Plain Pocketbook) and 105 shells were collected (Krebs et al. 2010b), a ratio of 17.5 to 1 . Comparatively, the 2012 survey of the Upper Cuyahoga River (Krebs et al.2012) produced almost equal numbers of living and shell specimens ( 410 shells and 385 living), the Upper Chagrin River above Chagrin Falls had a ratio less than one (179 shells to 231 living, or 0.77 shells/live, Krebs et al. 2010b), while Begley (2014) collected 961 live for just 181 shells in the adjacent Upper Mahoning River watershed, mostly in the more forested Eagle
Creek, a stream just east of the Cuyahoga River and over the northern divide in Portage County.

Because no mussel surveys had been conducted prior to removal of any of the Middle Cuyahoga River dams, we cannot attribute the decline in the lentic species to the removal of these features. But, only one site, which was above Kent, could be said to have a viable population of mussels. Thus, few individuals were found within regions once covered by dam pools, and the mussels found occurred where the riparian habitat now includes a thick layer of deciduous trees. While the most common land cover around the river was deciduous forest, commercial/industrial ranked second, especially in the area of downtown Cuyahoga Falls and Munroe Falls where three dams were removed. These areas remain under commercial development and possess little cover along riparian zones, which may limit the development of mussel habitat in these portions of the river.

Nonetheless, removal of dams has returned the river to a more natural state even though those removals must have imposed great disturbance (Stanley et al. 2002; Krieger and Zawiski 2013). Most of the stream bed below the old dam sites is now flowing riffles and shallow pools. Typically sediment deposits on the inside of a bend in the river, especially as the river begins to straighten on the downstream end (Newton et al. 2008). While not conducting formal substrate sampling, such geographic features were not yet apparent in the river. The many urbanized areas typically possess impervious surfaces that contribute both to rapid run-off and periods of high pollution and salt loads (Roy et al. 2015), suggesting that current land use remains a factor as well as the past dams.

A final challenge with respect to the Middle Cuyahoga River is its isolation. Connectivity to the Upper Cuyahoga, which sported a low diversity but abundant assemblage (Tevesz et al. 2002), may explain the species of shells found and asserts the common history of these two regions of the river. By contrast, the high slope of the gorge region naturally separates the Lower Cuyahoga River, which once had a diverse fauna (Dean 1890; Brose 1994), from the middle and upper reaches (Ortmann 1924). Therefore, even after the river stabilizes, repopulation will depend on survivors in the region. Colonization from up and downstream of the Middle Cuyahoga is effectively blocked by the gorge on the downstream side and by dreissenid-infested Lake Rockwell and its dam upstream. 


\section{ACKNOWLEDGMENTS}

Funds for this project were provided by the Summit Metro Parks and impetus for the project by their chief of natural resources, Mike Johnson. We thank Ramsey Langford (park employee) for his assistance in surveys. All work was carried out under permission of the Ohio Division of Wildlife under Permit 17-150, and permission of the Summit Metro Parks. We thank the reviewers for OJS, Rodney Sheets and Michael Hoggarth, who provided many suggestions to improve the manuscript.

\section{LITERATURE CITED}

Anthony JL, Downing JA. 2001. Exploitation trajectory of a declining fauna: a century of freshwater mussel fisheries in North America. Can. J. Fish Aquat. Sci. 58(10):2071-2090. https://doi.org/10.1139/cjfas-58-10-2071

Begley MT. 2014. Assessment of the freshwater mussel community of the Upper Mahoning River watershed and factors influencing diversity and abundance in small streams [master's thesis]. Cleveland (OH): Cleveland State University.

Brose DS. 1994. The South Park Village site and the late prehistoric Whittlesey Tradition of northeast Ohio. Madison (WI): Prehistory Press. (Monographs on world archeology, vol. 20). 226 p.

Craig AR, Krebs RA. 2014. A tale of Tinkers Creek and the unlikely return of freshwater mussels. Ellipsaria. 16(4):21-22.

Dean GW. 1890. Distribution of the Unionidae in the three rivers, Mahoning, Cuyahoga, and Tuscarawas. Nautilus. 4:20-22.

Doyle MW, Stanley EH, Orr CH, Selle AR, Sethi SA, Harbor JM. 2005. Stream ecosystem response to small dam removal: lessons from the heartland. Geomorphology. 71:227-244. https://doi.org/10.1016/j.geomorph.2004.04.011

Gottgens JF, Evans JE. 2007. Dam removals and river channel changes in northern Ohio: implications for Lake Erie sediment budgets and water quality. J. Great Lakes Res. 33(sp2):87-89. https://doi.org/10.3394/03801330(2007)33[87:DRARCC]2.0.CO;2

Graf DL. 2002. Historical biogeography and late glacial origin of the freshwater pearly mussel (Bivalvia: Unionidae) faunas of Lake Erie, North America. Occas. Pap. Mollusks. 6:175-211.

Haag WR, Rypel AL. 2011. Growth and longevity in freshwater mussels: evolutionary and conservation implications. Biol. Rev. 86(1):225-247. https://doi.org/10.1111/j.1469185X.2010.00146.x

Hardison BS, Layzer JB. 2001. Relations between complex hydraulics and the localized distribution of mussels in three regulated rivers. Reg. River Res. Manage. 17(1):77-84. https:// doi.org/10.1002/1099-1646(200101/02)17:1<77::AIDRRR604>3.0.CO;2-S

Hornbach DJ, Hove MC, Liu HT, Schenck FR, Rubin D, Sansom BJ. 2014. The influence of two differently sized dams on mussel assemblages and growth. Hydrobiologia. 724(1):279-291. https://doi.org/10.1007/s10750-013-1743-y

Krebs RA, Griffith HM, Tevesz MJS. 2002. A study of the Unionidae of Tinkers Creek, Ohio. Kirtlandia. 53:19-25.

Krebs RA, Borden WC, Steiner ER, Lyons MS, Zawiski W, Walton BM. 2010. Determinants of mussel diversity in Lake Erie tributaries. J. N. Am. Benthol. Soc. 29:506-520. https:// doi.org/10.1899/09-017.1
Krebs RA, Hook JD, Hoggarth MA, Walton BM. 2010. Evaluating the mussel fauna of the Chagrin River, A state listed "scenic" river in Ohio. Northe. Nat. 17:565-574. https://doi.org/10.1656/045.017.0404

Krebs RA, SredniawaSA, Andrikanich RE. 2012. Interconnectivity of the mussel fauna in the Geauga County highlands. Final report. Cleveland $(\mathrm{OH})$ : Cleveland State University. 13 p. http://www.geaugaparkdistrict.org/documents/SRG2012Mussel-Fauna.pdf

Krieger KA, Zawiski B. 2013. Changes in biotic and habitat indices in response to dam removals in Ohio. Rev. Eng. Geol. 21:105-116. https://doi.org/10.1130/2013.4121(09)

Mann KC, Peck JA, Peck MC. 2013. Assessing dam pool sediment for understanding past, present and future watershed dynamics: an example from the Cuyahoga River, Ohio. Anthropocene. 2:76-88. https://doi.org/10.1016/j. ancene.2013.08.001

Newton TJ, Woolnough DA, Strayer DL. 2008. Using landscape ecology to understand and manage freshwater mussel populations. J. N. Am. Benthol. Soc. 27:424-39. https:// doi.org/10.1899/07-076.1

OEPA. 1999. Biological and water quality study of the Cuyahoga River and selected tributaries. Vol. 1: Geauga, Portage, Summit, and Cuyahoga Counties (Ohio). Columbus (OH): Ohio Environmental Protection Agency. 141 p. http://www. epa.ohio.gov/portals/35/documents/cuyvol1.pdf

OEPA. 2000. Total maximum daily loads for the middle Cuyahoga River. Final report. Columbus (OH): Ohio Environmental Protection Agency, Division of Surface Water. 38 p. http:// www.epa.state.oh.us/portals/35/tmdl/MidCuyFinalTMDL. pdf

OEPA. 2003. Total maximum daily loads for the lower Cuyahoga River. Final report. Columbus (OH): Ohio Environmental Protection Agency, Division of Surface Water. 110 p. http:// www.epa.state.oh.us/portals/35/tmdl/Cuyahoga_lower_ final_report.pdf

Ortmann AE. 1919. A monograph of the naides of Pennsylvania. Part III: systematic account of the genera and species. Mem. Carnegie Mus. 8(1):xvi-385.

Ortmann AE. 1924. Distributional features of naiades in tributaries of Lake Erie. Am. Midl. Nat. 9:101-117. https:// doi.org/10.2307/2992800

Peck M. 2012. Middle Cuyahoga River watershed action plan. Draft. Akron (OH): Northeast Ohio Four County Regional Planning and Development Organization. http://www. nefcoplanning.org/

Pires LMD, Bontes BM, Samchyshyna L, Jong J, Van Donk E, Ibelings BW. 2007. Grazing on microcystin-producing and microcystin-free phytoplankters by different filter-feeders: implications for lake restoration. Aq. Sci. 69:534-543. https:// doi.org/10.1007/s00027-007-0916-z

PoffNL. 1992. Why disturbances can be predictable: a perspective on the definition of disturbance in streams. J. N. Am. Benthol. Soc. 11:86-92. https://doi.org/10.2307/1467885

PoffNL, Hart DD. 2002. How dams vary and why it matters for the emerging science of dam removal. BioScience. 52(8):659-668. https://doi.org/10.1641/0006-3568(2002)052[0659:HDVA WI]2.0.CO;2

Randklev CR, Wang H-H, Groce JE, Grant WE, Robertson S, Wilkins RN. 2015. Land use relationships for a rare freshwater mussel species endemic to central Texas. J. Fish Wildlife Man. 6(2):327-337. https://doi.org/10.3996/012015-JFWM-003

Randklev CR, Ford N, Wolverton S, Kennedy JH, Robertson C, Mayes K, Ford D. 2016. The influence of stream discontinuity 
and life history strategy on mussel community structure: a case study from the Sabine River, Texas. Hydrobiologia. 770(1):173-191. https://doi.org/10.1007/s10750-0152586-5

Resh VH, Brown AV, Covich AP, Gurtz ME, Li HW, Minshall GW, Reice SR, Sheldon AL, Wallace JB, Wissmar RC. 1988. The role of disturbance in stream ecology. J. N. Am. Benthol. Soc. 7:433-455. https://doi.org/10.2307/1467300

Roy JW, McInnis R, Bickerton G, Gillis PL. 2015. Assessing potential toxicity of chloride-affected groundwater discharging to an urban stream using juvenile freshwater mussels (Lampsilis siliquoidea). Sci. Total Environ. 532:309-315. https://doi. org/10.1016/j.scitotenv.2015.06.023

Schwalb AN, Morris TJ, Mandrak NE, Cottenie K. 2013. Distribution of unionid freshwater mussels depends on the distribution of host fishes on a regional scale. Divers Distrib. 19(4):446-454. https://doi.org/10.1111/j.14724642.2012.00940.x

Scott MW, Begley MT, Krebs RA, Zanatta DT. 2014. Mitochondrial DNA variation in the Eastern Pondmussel, Ligumia nasuta (Bivalvia: Unionoida) in the Great Lakes region. Walkerana. 17(2):60-67.

Sethi SA, Selle AR, Doyle MW, Stanley EH, Kitchel HE. 2004. Response of unionid mussels to dam removal in Koshkonong Creek, Wisconsin (USA). Hydrobiologia. 525(1):157-165. https://doi.org/10.1023/B:HYDR.0000038862.63229.56

Stanley EH, Doyle MW. 2003. Trading off: the ecological effects of dam removal. Front. Ecol. Environ. 1(1):15-22. https:// doi.org/10.1890/1540-9295(2003)001[0015:TOTEEO]2 .0. $\mathrm{CO} ; 2$

Stanley EH, Luebke MA, Doyle MW, Marshall DW. 2002. Short-term changes in channel form and macroinvertebrate communities following low-head dam removal. J. N. Am. Benthol. Soc. 21:172-187.https://doi.org/10.2307/1468307

Stradling D, Stradling R. 2008. Perceptions of the burning river: deindustrialization and Cleveland's Cuyahoga River. Environ. Hist. 13(3):515-535. https://doi.org/10.1093/ envhis/13.3.515

Tevesz MJS, Rundo L, Krebs RA, Redmond BG, Dufresne AS. 2002. Changes in the freshwater mussel (Bivalvia: Unionidae) fauna of the Cuyahoga River, Ohio, since late prehistory. Kirtlandia. 53:13-18.

Tuckerman S, Zawiski B. 2007. Case studies of dam removal and TMDLs: Process and results. J. Great Lakes Res. 33(sp2):103116. https://doi.org/10.3394/0380-1330(2007)33[103:CS ODRA]2.0.CO;2

Tullos DD, Finn DS, Walter C. 2014. Geomorphic and ecological disturbance and recovery from two small dams and their removal. PLoS ONE. 9(9):e108091.https://doi.org/10.1371/ journal.pone.0108091

Vaughn CC, Taylor CM. 2000. Macroecology of a hostparasite relationship. Ecography. 23(1):11-20. https://doi. org/10.1111/j.1600-0587.2000.tb00256.x

Watters GT. 1996. Small dams as barriers to freshwater mussels (Bivalvia, Unionoida) and their hosts. Biol. Conserv. 75(1):7985. https://doi.org/10.1016/0006-3207(95)00034-8

Watters GT, Hoggarth MA, Stansbery DH. 2009. The Freshwater Mussels of Ohio. Columbus $(\mathrm{OH})$ : The Ohio State University Press.

Wisniewski JM, Shea CP, Abbott S, Stringfellow RC, Carson R. 2013. Imperfect recapture: a potential source of bias in freshwater mussel studies. Am. Midl. Nat. 170(2):229-247. https://doi.org/10.1674/0003-0031-170.2.229

Zanatta DT, Bossenbroek JM, Burlakova LE, Crail TD, de
Szalay F, Griffith TA, Kapusinski D, Karateyev AY, Krebs RA, Meyer ES, et al. (2015). Distribution of native mussel (Unionidae) assemblages in coastal areas of Lake Erie, Lake St. Clair, and connecting channels, twenty-five years after a dreissenid invasion. Northe. Nat. 22:223-235. https://doi. org/10.1656/045.022.0115 